\title{
TEKNOLOGI PENANGKAPAN IKAN PADA MASYARAKAT NELAYAN DI NAGARI PASAR LAMA AIR HAJI, KECAMATAN LINGGOSARI BAGANTI, KABUPATEN PESISIR SELATAN
}

\author{
Ermayanti ${ }^{1}$, Nursyirwan Effendi ${ }^{2}$, Muhammad Hidayat ${ }^{3}$
}

\begin{abstract}
In the fishing community, fisheries economic sector will not be released to the role of traditional fisheries technology in various forms, such as ship or boat, fishing net (Wareng). Conditions of fishing tools that is still largely traditional and the number of workers is still high fisherman showing the condition of Pasar Lama Muaro Air Haji villages classified as areas considered to have pockets of poverty. This makes the fishing could not be further moves towards its efforts to develop the technology of fishing
\end{abstract}

\section{Keywords: Fishermen, Traditional fisheries technology, Village, Local Cultural}

\section{PENDAHULUAN}

1. Latar Belakang Masalah

$\mathrm{M}$ asyarakat pesisir didefinisikan sebagai kelompok orang yang tinggal di daerah pesisir dan sumber kehidupan perekonomiannya bergantung secara langsung pada pemanfaatan sumberdaya laut dan pesisir. Definisi inipun bisa juga dikembangkan lebih jauh karena pada dasarnya banyak orang yang hidupnya bergantung pada sumberdaya laut. Mereka terdiri dari nelayan pemilik, buruh nelayan, pembudidaya ikan dan organisme laut lainnya, pedagang ikan, pengolah ikan, supplier faktor sarana produksi perikanan (Zamzami, 2007).

Masyarakat pesisir, yakni bermatapencaharian sebagai nelayan selama ini dianggap sebagai kelompok masyarakat miskin yang termiskin (the poorer of the poorest people). Kemiskinan yang melanda kehidupan nelayan disebabkan oleh faktor-faktor yang kompleks dimana faktor-faktor tersebut tidak hanya berkaitan dengan fluktuasi musim-musim ikan, kertebatasan sumberdaya manusia, modal serta akses, jaringan pedagang ikan yang eksploitatif terhadap nelayan sebagai produsen tetapi juga disebabkan oleh dampak negatif modernsasi perikanan yang mendorong terjadi pengurasan sumberdaya laut secara berlebihan. Hasil-hasil studi tentang tingkat kesejahteraan hidup di kalangan nelayan telah menunjukkan bahwa kemiskinan dan kesenjangan sosial ekonomi atau ketimpangan pendapatan merupakan persoalan krusial yang dihadapi nelayan dan tidak mudah diatasi (Satria, 2002; Sugiharto, dkk, 2013).

Nelayan adalah istilah bagi orangorang yang sehari-harinya bekerja menangkap ikan atau biota lainnya yang hidup di dasar, kolom maupun permukaan perairan. Perairan yang menjadi daerah aktivitas nelayan ini dapat merupakan perairan tawar, payau maupun laut. Di negara-negara berkembang seperti di Asia Tenggara atau di Afrika, masih banyak nelayan yang menggunakan peralatan yang sederhana dalam menangkap ikan. Nelayan di negara-negara maju biasanya menggunakan peralatan modern dan kapal yang besar yang dilengkapi teknologi canggih (Kusnadi, 2000).

Nelayan artisanal yang termasuk sebagai small scale fishery adalah orang pemilik perahu yang sebagian besar penghasilannya bergantung pada kegiatan penangkapan ikan di laut, mengoperasikan

\footnotetext{
${ }^{1}$ Penulis adalah Dosen tetap Jurusan Antropologi FISIP Universitas Andalas

2 Penulis adalah Dosen tetap Jurusan Antropologi FISIP Universitas Andalas

${ }^{3}$ Penulis adalah Dosen luar biasa Jurusan Antropologi FISIP Universitas Andalas
} 
sendiri perahunya dengan ukuran berat perahu antara 2,75-25 GT (atau ukuran panjang perahu antara 5 meter hingga 15 meter, lebar antara 1,5 meter hingga 6 meter menggunakan peralatan tangkap ikan sederhana (seperti gilnet, jaring badut, minitrawl, pancing, rawai pancang), menggunakan sistem penghasilan bagi hasil antara pemilik dan anak buah kapal, dan menjual hasiltangkapan ikan dalam lingkup pasar lokal yang terbatas (Charles (2001), Satria (2002), Luky (2007)). Di Indonesia masyarakat nelayan merupakan salah satu golongan masyarakat yang dianggap miskin secara absolut, bahkan paling miskin diantara penduduk miskin (the poorest of the poor; Mukflihati, 2010). Berbagai studi juga telah menunjukkan bahwa kondisi nelayan,khususnya nelayan perikanan skala kecil di Indonesia berada pada tingkat marjinal (Kusnadi, 2000; Semedi, 2003; Budi, 2008; Prihandoko, dkk, 2011).

Sistem kegiatan perikanan tangkap nelayan artisanal terdiri atas 4 (empat) aspek kegiatan (Kusnadi, 2000; Charles, 2001). Pertama adalah kegiatan dalan bidang penggunaan teknologi alat tangkap dan alat bantu tangkap berkait dengan capital dynamics, yaitu armada, alat tangkap (fleet) dan alat bantu tangkap yang mendorong hasil tangkapan maksimal dengan dampak seminimal mungkin terhadap lingkungan fisik. Kedua, kegiatan dalam bidang kegiatan persiapan dan operasi penangkapan yang berisi tentang kemampuan nelayan menentukan waktu musim ikan, lokasi penangkapan ikan, ukuran dan jenis ikan yang boleh ditangkap serta kondisi cuaca yang memungkinkan untuk melaut. Ketiga, kegiatan dalam bidang pengerahan tenaga kerja dan modal yang berisi tentang kemampuan nelayan untuk mengoptimalkan tenaga kerja dan modal yang ada dalam mengoperasikan perahu beserta alat tangkap. Keempat, kegiatan dalam bidang menjaga mutu hasil tangkapan dan pemasaran ikan berkait dengan kemampuan nelayan mengupayakan mutu ikan yang baik tetap terjaga untuk mencapai harga jual ikan yang setinggi-tingginya (Prihandoko, dkk, 2011).

Pada umumnya, masyarakat yang tinggal di tepi-tepi pantai laut terutama di kawasan pesisir pantai barat sumatera bermata pencaharian sebagai nelayan sebagian besar menggunakan teknologi penangkapan ikan yang masih bersifat tradisional dan sebagian kecil memiliki alat penangkapan yang modern. Secara garis besar nelayan berdasarkan alat penangkapan ikan dapat dibedakan atas dua golongan, yaitu : 4

1. Nelayan berdasarkan pemilikan alat penangkapan, yang terbagi atas :

a. Nelayan pemilik, yaitu nelayan yang mempunyai alat penangkapan, baik yang langsung turun ke laut maupun yang langsung menyewakan alat tangkapan kepada orang lain.

b. Nelayan Buruh atau nelayan penggarap, yaitu nelayan yang tidak memiliki alat penangkap, tetapi mereka menyewa alat tangkap dari orang lain atau mereka yang menjadi buruh atau pekerja pada orang yang mempunyai alat penangkapan.

2. Berdasarkan sifat kerjanya nelayan, dapat dibedakan atas :

a. Nelayan penuh atau nelayan asli, yaitu nelayan baik yang mempunyai alat tangkap atau buruh yang berusaha semata-mata pada sektor perikanan tanpa memiliki usaha yang lain.

b. Nelayan Sambilan, yaitu nelayan yang memiliki alat penangkapan atau juga sebagai buruh pada saat tertentu melakukan kegiatan pada sektor perikanan disamping usaha lainnya (Zamzami, 2007)

Secara sosial budaya, dikemukakan bahwa masyarakat nelayan memiliki ciri-ciri yang saling terkait antara satu dengan yang lainnya. Alasannya adalah (1) terdapat interaksi sosial yang intensif antara warga masyarakat, yang ditandai dengan efektifnya komunikasi tatap muka, sehingga terjadi hubungan yang sangat erat antara satu dengan yang lainnya. Dengan demikian hal tersebut dapat membangun terjalinnya hubungan kekeluargaan yang didasarkan pada simpati dan bukan berdasarkan kepada pertimbangan rasional yang berorientasi kepada untung rugi .(2) bahwa dalam mencari nafkah mereka menonjolkan sifat gotong royong dan saling membantu. Hal tersebut dapat diamati pada mekanisme

\footnotetext{
${ }^{4}$ Dirjen Kebudayaan Depdikbud, 1997, Budaya Kerja Nelayan Indonesia di Jawa Timur, CV Bupara Nugraha, Jakarta, Hal. 686
} 
menangkap ikan baik dalam cara penangkapan masupun dalam penentuan daerah operasi. ${ }^{5}$

Selain daripada itu, masyarakat nelayan yang bercirikan tradisional kurang berorientasi kepada masa depan, penggunaan teknologi masih sederhana, kurang rasional, relatif tertutup terhadap orang luar, dan kurang berempati. ${ }^{6}$ Pada zaman nenek moyang dahulu, para nelayan hanya menggunakan alat-alat yang sangat sederhana, seperti perahu yang kecil dengan pendayung yang kecil pula. Sekarang para nelayan telah menggunakan teknologi yang sudah maju, misalnya dengan memakai mesin tempel sebagai alat penggerak perahu serta alat penangkapan yang lebih baik.

Keberadaan alat-alat penangkapan yang modern tersebut menjadikan masyarakat dapat menangkap ikan lebih banyak lagi dan waktu yang diperoleh dari hasil penangkapan ikan relatif kecil. Meskipun demikian, teknologi modern tersebut tidak sepenuhnya dikembangkan oleh nelayan. Masyarakat nelayan di Indonesia terutama di kawasan pesisir barat sumatera masih melaksanakan kegiatan di laut secara tradisional, seperti menangkap ikan dengan jala, pancing dan lainnya sehingga secara ekonomi mereka masih kurang beruntung, padahal kalau dilihat dari hasil penangkapan di laut secara keseluruhan sangat banyak. ${ }^{7}$

5 Dra. Slfema MPd, 2002, Makalah Wanita Dalam Masyarakat Nelayan : Latar Kehiudpan dan Potensi Pengembangannya, Disajikan dalam Seminar Budaya Pesisir dan Kondisi Potensi Kelautan Sumatera Barat, Museum Adityawarman Padang, tanggal 29 Agustus 2002, Hal. 3-4.

6 Pada umumnya masyarakat nelayan dapat dogolongkan sebagai masyarakat kelas bawah sosial. Menurut Wisroni (2000), masyarakat kelas sosial bawah termask golongan ekonomi lemah. Seperti dalam kalangan petani, nelayan bukanlah pemilik lahan pertanian yang memadai, kebanyakan nelayan hanyalah sebagai orang yang bekerja pada sejumlah kecil juragan yang memiliki kapal.

7 Menurut Martusubroto - seperti yang dikutip oleh Syahrizal (2000 : 5 ) - bahwa hampir $90 \%$ nelayan di Indonesia masih berskala kecil dan lebih dari $60 \%$ dari mereka hidup di bawah garis kemiskinan. Ini artinya bahwa

\section{Perumusan Masalah}

$\mathrm{K}$ awasan perikanan pantai Sumatera Barat meliputi 6 (enam) daerah Kabupaten dan Kota, yaitu Pasaman, Agam, Padang Pariaman dan Pesisir Selatan serta Kepulauan Mentawai dengan jumlah nelayan sejumlah 32.367 orang yang terdiri atas 24.373 orang nelayan tetap dan sisanya sebanyak 7.994 orang adalah nelayan musiman. Jumlah perahu penangkapan adalah 7.526 yang terdiri atas perahu tanpa motor (4.399), perahu motor tempel (1.696) dan kapal motor (1.431). ${ }^{8}$

Lokasi daerah yang akan dipilih dalam penelitian ini adalah Nagari Pasar Lamo Muaro Air Haji, Kecamatan Linggosari Baganti, Kabupaten Pesisir Selatan. Di nagari Pasar Lamo Muaro Air Haji, umumnya mata pencaharian masyarakatnya adalah sebagai nelayan dan merupakan kawasan perkampungan nelayan yang terletak dalam wilayah Kecamatan Linggosari Baganti. Masyarakat nelayan di pesisir barat Sumatera Barat sebagian besar menggunakan metode penangkapan perikanan berdasarkan cara-cara penangkapan ikan yang masih bersifat tradisional, yaitu menangkap ikan dengan membagan, memayang, memukat dan menjaring dengan masing-masing jenis perahu/kapal yang berbeda. ${ }^{9}$ Dari metode

sebagian besar nelayan Indonesia masih nelayan tradisional, karena mereka masih menggunakan perahu-perahu kecil untuk mencari ikan dan hasil yang didapat biasanya juga untuk memenuhi kebutuhan primer sehari-hari. Mereka lebih dipengaruhi oleh pengetahuan rakyat dalam kaitannya dengan pekerjaan mereka sebagai nelayan karen akses kepada ilmu pengetahuan modern hampir tidak ada.

8 Firial Marahudin, Kebijaksanaan Pembangunan Kelautan dan Perikanan, Sumatera Barat, Seminar di museum Adityawarman tanggal 29 Agustus 2002, Hal.4

9 Membagan adalah menangkap ikan yang dilakukan pada malam hari dengan mempergunakan sebuah kapal yang disebut BAGAN, ukuran bagan panjangnya berkisar antara 12 sampai $20 \mathrm{~m}$ dan, lebar 2 sampai 4 m. jumlah anggotanya 6-7 orang yang dilengkapi dengan lampu sebanyak 100-150 buah. Memayang adalah menangkap ikan yang dilakuan pada siang hari dengan menggunakan 
penangkapan ikan masyarakat nelayan tersebut, di Nagari Pasar Lamo Muara Air Haji terdapat 2 metode penangkapan ikan yaitu dengan cara membagan dan memukat. Dengan kondisi tersebut terdapat beberapa tantangan masyarakat nelayan, seperti kurang baiknya kondisi ekonomi keluarga, makin banyaknya kapal-kapal nelayan yang beroperasi dalam jumlah yang besar sehingga masyarakat nelayan tergolong masyarakat yang miskin. Dengan semakin banyaknya teknologi penangkapan ikan, seperti jumlah perahu penangkapan yang semakin meningkat, maka masyarakat nelayan lokal dituntut untuk dapat mengembangkan teknologi perikanan yang lebih baik lagi melalui budaya lokal supaya mereka tidak tersingkir oleh keberadaan kapal-kapal modern nelayan lainnya. Budaya teknologi perikanan yang harus mereka kembangkan berupa cara penangkapan ikan yang relatif modern, pemasaran ikan dan terutama pembuatan kapal perahu yang sesuai dengan teknologi perikanan yang mereka pergunakan.

Berdasarkan latar belakang di atas, permasalahan yang ingin dilihat adalah bagaimana gambaran teknologi penangkapan perikanan masyarakat nelayan yang selama ini dipergunakan berdasarkan konsep budaya lokal setempat?

\section{Tujuan Penelitian}

$\mathrm{P}$ enelitian in mendeskripsikan ni bertujuan penangkapan perikanan masyarakat nelayan yang selama ini dipergunakan yang dipengaruhi oleh budaya lokal, terutama cara-cara penangkapan ikan dan hubungannya dengan aktivitas penangkapan ikan di laut.

Lokasi yang dipilih sebagai wilayah penelitian adalah di Nagari Pasar Lamo

sebuah kapal yang disebut dengan PAYANG. Jumlah anggotanya terdiri dari 10-12 orang. Ukuran panjangnya antara 8-12 $\mathrm{m}$ dan lebar berkisar 1-2 m. Memukat adalah menangkap ikan yang dilakukan di tepi laut. Jumlah anggotanya antara 5-7 orang dan Menjaring adalah menangkap ikan yang dilakukan ke tengah laut dengan menggunakan perahu ukuran kecil dengan cara didayung.
Muaro Air Haji, Kecamatan Linggosari Baganti, Kabupaten Pesisir Selatan. Lokasi ini dipilih karena berada di wilayah pesisir pantai Barat Sumatera yang memiliki lebih dari 1000 orang nelayan yang aktif dalam aktivitas perikanan dan kelautan.

Dalam penelitian ini menggunakan pendekatan penelitian kualitatif. Penelitian kualitatif memusatkan perhatian pada prinsip-prinsip umum yang mendasari perwujudan satuan-satuan gejala yang ada dalam kehidupan sosial. Dalam penelitian kualitatif yang dianalisis bukan variabelvariabel tetapi yang dianalisis dalam kaitan hubungan dengan prinsip-prinsip umum dari satuan-satuan gejala lainnya dengan menggunakan budaya masyarakat yang diteliti dan dari hasil analisis tersebut dianalisis lagi dengan menggunakan seperangkat teori yang berlaku (Neuman, 2006:149; Rudito, 2008: 78)

Teknik pengumpulan data yang telah dilakukan adalah menggunakan teknik observasi partisipasi, wawancara bebas dan mendalam dan studi kepustakaan. Pemilihan informan dengan situasi sosial tertentu, dengan sendirinya, perlu dilakukan secara purposif (bukan secara acak), yaitu atas dasar apa yang diketahui tentang variasi-variasi yang ada atau elemenelemen yang ada. Pemilihan informan yang purposif seperti yang dijelaskan di atas, juga dikenal istilah dengan teknik snowball sampling. Cara ini banyak dipakai ketika peneliti tidak banyak tahu tentang populasi penelitiannya. Peneliti hanya tahu satu atau dua orang yang berdasarkan penilaiannya bisa dijadikan informan. Karena peneliti menginginkan lebih banyak lagi, maka peneliti akan minta kepada informan pertama untuk menunjukan orang lain yang kira-kira bisa dijadikan informan.

Ada pun kriteria informan dalam penelitian ini adalah:

- Nelayan yang telah beraktivitas selama lebih dari 10-20 tahun

- Tokoh masyarakat, tokoh agama, atau tokoh adat yang mengetahui budaya setempat.

Data-data yang telah dikumpulkan oleh peneliti termasuk juga catatan lapangan dikelompokkan oleh peneliti atas dasar aktivitas khusus yang ada dan diteliti. Kemudian dari pengelompokkan data tersebut, data-data itu kemudian diabstraksikan dan dikaitkan satu dengan 
lainnya sebagai satu kesatuan kejadian dan fakta yang terintegrasi. Dari abstraksi tersebut maka akan tampak pranata sosial yang berlaku di wilayah atau komuniti tersebut (Bungin, 2004:60). Dalam menganalisis tentunya selalu terkait dengan konsep yang telah dipelajari sebelumnya. Sehingga dari hasil analisis akan tampak kesesuaian dari data yang diperolehnya dengan konsep yang dipelajarinya atau akan berbeda dengan konsep yang dipelajarinya karena masalah sosial akan selalu berbeda antara satu masyarakat dengan masyarakat lainnya. Setelah itu disusun sesuai dengan kategori-kategori dan kemudian disimpulkan. Apabila dalam kesimpulan masih menimbulkan keraguan maka dilakukan pengkategorian ulang hingga seluruh data yang telah berhasil dikumpulkan dianggap sesuai dengan tujuan penelitian. Temuan di lapangan akan diolah dengan data yang didapat dari literatur dan akan disajikan dalam suatu karya etnografi deskriptif.

\section{KAJIAN PUSTAKA}

$\mathrm{M}$ anusia dalam kehidupannya dituntut melakukan suatu usaha untuk mendatangkan hasil dalam pemenuhan kebutuhan hidupnya. Usaha yang dilakukan dapat berupa tindakantindakan untuk memperoleh dan memanfaatkan sumber-sumber daya yang memiliki nilai ekonomis guna memenuhi syarat-syarat minimal atau kebutuhan dasar agar dapat bertahan hidup, dimana kebutuhan dasar merupakan kebutuhan biologis dan lingkungan sosial budaya yang harus dipenuhi bagi kesinambungan hidup individu dan masyarakat (Imran, 1989).

Kebudayaan adalah keseluruhan pengetahuan manusia sebagai mahluk sosial yang digunakan untuk memahami dan menginterpretasikan lingkungan dan pengalamannya serta menjadi kerangka landasan bagi terwujudnya kelakuan. Kebudayaan juga dilihat sebagai seperangkat mekanisme-mekanisme kontrol, yaitu rencana-rencana, resep-resep, aturan-aturan, instruksi-instruksi untuk mengatur tingkah laku (Geertz, 1992) Dalam kehidupan masyarakat nelayan, kebudayaan umum lokal setempat sangat mempengaruhi aktivitas mereka dalam meningkatkan kesejahteraan ekonomi masyarakat nelayan.

Dilihat dari prespektif antropologis, masyarakat nelayan berbeda dari masyarakat lain, seperti masyarakat petani, perkotaan atau masyarakat di dataran tinggi. Prespektif antropologis ini didasarkan pada realitas sosial bahwa masyarakat nelayan memiliki pola-pola kebudayaan yang berbeda dari masyarakat lain sebagai hasil dari interaksi mereka dengan lingkungan beserta sumber daya yang ada didalamnya. Pola-pola kebudayaan itu menjdai kerangka berpikir atau referensi perilaku masyarakat nelayan dalam menjalani kehidupan seharihari (Kusnadi, 2005).

Perikanan adalah kegiatan ekonomi dalam bidang penangkapan atau budidaya ikan atau binatang air lainnya serta tanaman air. Penangkapan adalah kegiatan penangkapan atau mengumpulkan ikan atau binatang air lainya serta tanaman air yang hidup dilaut atau perairan umum secara bebas dan bukan milik perorangan. Pada umumnya penangkapan ditujukan kepada ikan atau binatang air lainnya serta tanaman air yang masih hidup. Pengumpulan kerang dan lain-lain juga termasuk sebagai penangkapan (Anonimus, 2008).

Penangkapan ikan yang dilakukan nelayan secara kuantitas tergantung pada perahu, peralatan tangkap yang digunakan maupun faktor lain seperti musim dan air pasang. Dengan perahu dan peralatan tangkap yang sesuai dan layak dioperasikan maka hasil tangkapan menjadi lebih baik dan dapat memberikan jaminan hidup bagi rumah tangganya (Rangkuti,1995).

Nelayan adalah orang yang secara aktif melakukan pekerjaan dalam operasi penangkapan ikan atau binatang air. Orang hanya melakukan pekerjaan seperti membuat jaring, mengangkut alatalat perlengkapan ke dalam perahu, tidak dimasukan sebagai nelayan. Tetapi ahli mesin dan juru masak yang bekerja diatas perahu penangkapan dimasukan sebagai nelayan, walaupun tidak secara langsung mereka melakukan penangkapan (Anonimus, 2008).

Berdasarkan waktu yang digunakan untuk melakukan pekerjaan operasi penangkapan, nelayan diklasifikasikan sebagai berikut : 
1. Nelayan penuh yaitu nelayan yang seluruh waktu kerjanya digunakan untuk melakukan pekerjaan operasi penangkapan ikan atau binatang air lainnya serta tanaman air.

2. Nelayan sambilan utama yaitu nelayan yag sebagian besar waktu kerjanya dilakukan untuk melakukan pekerjaan operasi penangkapan ikan atau binatang air lainya serta tanaman air disamping melakukan pekerjaan penangkapan, nelayan kategori ini memiliki pekerjaan lain.

3. Nelayan sambilan tambahan, yaitu nelayan yang sebagian besar waktu kerjanya tidak digunakan untuk melakukan pekerjaan penangkapan ikan (Anonimus, 2008).

Berdasarkan perahu penangkap ikan, nelayan pemilik dibagi menjadi nelayan tradisional dan nelayan bermotor. Nelayan tradisional memakai perahu tanpa mesin/motor. Sedangkan nelayan bermotor memakai perahu mempunyai mesin (motor) yang disebut perahu motor. Berdasarkan besarnya mesin (motor) yang digunakan, diukur dengan GT (Gross Tonage), Perahu motor dibagi menjadi:

1. Perahu kecil yaitu $<5$ GT $-10 \mathrm{GT}$, dengan panjang kurang dari 9 meter.

2. Perahu sedang yaitu $10 \mathrm{GT}-30 \mathrm{GT}$ , dengan panjang 9-11 meter.

4. Perahu besar yaitu lebih dari $30 \mathrm{GT}$ , dengan panjang 11 meter atau lebih (Anonimus,2001).

Pengelolaan perikanan berkembang menjadi suatu seni dalam menyelesaikan antara produksi perikanan dengan kondisikondisi ekonomi. Misalnya karena permintaan ikan makin meningkat dan harganya semakin tinggi maka menarik para pengusaha untuk menambah armada penangkapannya. Tetapi dilain pihak para pengelola harus bisa membatasi daya tangkap perahu agar jumlah tangkapan tetap berada pada batas-batas tertentu. Dalam pengelolaan perikanan dikenal beberapa konsep pembatasan berusaha, antara lain adalah:

a. Pembatasan upaya penangkapan yang dilakukan dengan mempersingkat waktu penangkapan atau membatasi peralatan yang digunakan

b. Membatasi jumlah modal dan tenaga kerja yang digunakan pada suatu usaha perikanan.

Untuk daya guna ekonomi pembatasan berusaha dilakukan dengan mewujudkan keinginan untuk menekan biaya serendah-rendahnya untuk melakukan upaya penangkapan yang menguntungkan (R.L. Strokes,1979). Secara kasar sumber daya perikanan laut dapat dibagi dalam 6 kelompok besar, yaitu krustasea, demersal, pelagis besar, pelagis kecil, perairan karang dan biota laut non ikan lainnya. Kelompok sumber daya ikan tersebut sekaligus menunjukkan kekhususan teknologi alat penangkap yang dipergunakan bagi pemanfaatnya (Barus,dkk.1991).

\section{PEMBAHASAN HASIL PENELITIAN 3.1 Gambaran Lokasi Penelitian}

$\mathrm{N}$ agari $^{10}$ Pasar Lama Muara Air Haji terletak di Kecamatan Linggosari Baganti, Kabupaten Pesisir Selatan, Sumatera Barat. Nagari Pasar Lama Muara Air Haji terdiri dari 2 jorong ${ }^{11}$, yang terdiri: Jorong Kampung Pasar Lama dan Jorong Kampung Muara Air Haji. Jumlah jorong yang berada di daerah pesisir sebanyak 1 buah (45\%) dan 1 jorong bukan pesisir (55\%), dengan jumlah penduduk pesisir dengan mata pencaharian sebagai nelayan sebanyak $59 \mathrm{KK}$. Batas wilayah administrasi Pemerintahan Nagari Pasar Lama Muara Air Haji adalah:

a) Sebelah Utara berbatasan dengan Pemerintah Nagari Punggasan.

\footnotetext{
${ }^{10}$ Nagari sendiri berasal dari bahasa Sansekerta, dalam bahasa Indonesia berarti kota (ibu kota), istana dan negara atau kerajaan sehingga Minangkabau nagari sering disebut dengan "republik kecil". Nagari adalah pembagian wilayah administratif di propinsi Sumatera Barat di bawah kecamatan yang dipimpin oleh seorang wali nagari.

11 Jorong adalah satu kesatuan di dalam masyarakat yang tinggal di suatu daerah tertentu. Setiap jorong memiliki pemimpin yang disebut wali Jorong yang berada di bawah pemerintahan nagari.
} 
b) Sebelah Selatan berbatasan dengan Pemerintah Nagari Air Haji Barat.

c) Sebelah Barat berbatasan dengan Samudera Indonesia. d) Sebelah Timur berbatasan dengan Pemerintahan Nagari Air Haji.

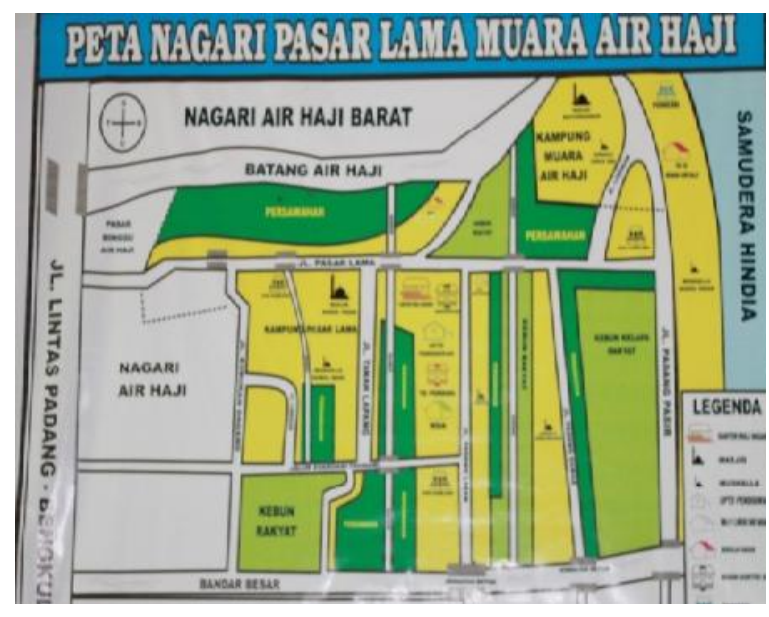

Gambar 1. Peta Wilayah Administrasi Nagari Pasar Lama Muaro Air Haji, Kec. Linggosari Baganti, Kabupaten Pesisir Selatan

minimum $20{ }^{\circ} \mathrm{C}$ dengan curah hujan dan

Nagari Nagari Pasar Lama Muara Air Haji terletak pada 10052 - 1017 BT dan 149,53 - 1 Lintang selatan. Nagari ini memiliki ketinggian dari permukaan laut lebih kurang 2,5 m sampai dengan $7 \mathrm{~m}$, suhu udara maksimum $31{ }^{\circ} \mathrm{C}$ dan suhu jumlah hari hujan pada Oktober 2010 ini rata-rata $308 \mathrm{~m} /$ bulan dan 17 hari/bulan. Wilayah ini terdiri dari dataran rendah, dengan tinggi pesisir pantai yang rendah. Penggunaan lahan dan luas wilayah secara terperinci dapat dilihat pada tabel berikut ini:

Tabel 1. Penggunaan Lahan dan Luas Wilayah di Pasar Lama Muara Air Haji

\begin{tabular}{|l|c|c|}
\hline \multicolumn{1}{|c|}{ Penggunaan Lahan } & Luas Wilayah & Persentase \\
\hline Perumahan dan Pekarangan & $18 \mathrm{Ha}$ & $1 \%$ \\
\hline Sawah teririgasi & $358 \mathrm{Ha}$ & $15 \%$ \\
\hline Sawah tadah hujan & $62 \mathrm{Ha}$ & $3 \%$ \\
\hline Perkebunan & $804 \mathrm{Ha}$ & $32 \%$ \\
\hline Hutan Negara & $1224 \mathrm{Ha}$ & $49 \%$ \\
\hline JUMLAH & $2466 \mathrm{Ha}$ & $100 \%$ \\
\hline
\end{tabular}

Sumber: Profil Pasar Lama Air Haji, 2013

Berdasarkan penggunaan lahan dan luas wilayah tersebut diatas menjelaskan bahwa penggunaan lahan hutan negara dan lahan persawahan yang memiliki aliran irigasi mendominasi luas wilayah di Pasar Lama Muara Air Haji terletak di Kecamatan Linggosari Baganti, Kabupaten Pesisir Selatan. Nagari Pasar Lama Muara Air Haji memiliki garis pantai yang cukup panjang dan juga memiliki keindahan dari aspek pemandangan lautnya.

\subsection{Sejarah Nagari}

B erdasarkan hasil wawancara dengan Bapak Amardi (Sekretaris Nagari) bahwa Nama Nagari Pasar Lama Muara Air Haji menurut cerita yang berkembang dan diyakini di tengah-tengah masyarakat bahwa menurut sejarah bermula dari tapian aie (pinggiran sungai) di hulu Sungai Lubuk Pakih. Di tapian air tersebut, tinggalh seorang yang baik hati bernama "Aji". Karena tempatnya yang landai serta airnya yang jernih menjadi daya tarik bagi kebanyakan orang untuk datang dan mandi di tapian itu. Bergitu digemarinya tapian itu, 
masyarakat menamakannya sebutan "Air Haji”. Karena kemurahan hari si Aji tersebut, masyarakat diperbolehkan untuk tinggal dan membuat rumah di dekat tapian tersebut sehingga tapian tersebut menjadi ramai dan berkembang menjadi sebuah perkampungan yang mereka namakan dengan "Aia Haji". Seiring dengan perubahan zaman, kampung terebut berkembang menjadi sebuah nagari yang disebut dengan Air Haji.

Seiring dengan itu dinamika penyelenggaraan Pemerintahan Nagari menunjukkan bahwa percepatan pelayanan publik yang efektif dan efisien merupakan kebutuhan bagi masyarakat. Hal ini ditunjukkan dengan munculnya aspirasi masyarakat yang menghendaki dilakukannya pemekaran terhadap Pemerintahan Nagari yang sudah ada menjadi beberapa Pemerintahan Nagari baru.

Lahirnya Pemerintahan Nagari Pasar Lama Muara Air Haji merupakan bentuk kebijakan pemerintah daerah untuk menyikapi aspirasi masyarakat yang menginginkan dimekarkannya Pemerintahan Nagari Air Haji (Pemerintahan Nagari awal) menjadi 9 (Sembilan ) Pemerintahan Nagari yaitu :

a) Pemerintahan Nagari Pemerintahan Nagari Air Haji;

b) Pemerintahan Nagari Air Haji Tenggara:

c) Pemerintahan Nagari Pasar Lama Muara Air Haji;

d) Pemerintahan Nagarai Air Haji Barat;

e) Pemerintahan Nagari Pasar Bukit Air Haji;

f) Pemerintahan Nagari Air Haji Tengah;

g) Pemerintahan Nagari Rantau Simalenang Air Haji;

h) Pemerintahan Nagari Muara Gadang Air Haji;

i) Pemerintahan Nagari Sungai Sirah Air Haji.

Atas dasar itulah Pemerintah Daerah bersama Dewan Perwakilan Rakyat
Daerah (DPRD) merespon aspirasi dan keinginan masyarakat Nagari Air Haji dengan melakukan kajian teknis, administratif dan melalui tahapan pembahasan sesuai dengan ketentuan perundang-undangan. Suatu penekanan penting yang perlu dipahami bahwa tindakan memekarkan Pemerintahan Nagari yang sudah ada sebagai wilayah penyelenggaraan urusan pemerintahan tidak diikuti dengan melakukan pemekaran Kerapatan Adat Nagari (KAN) sebagai wilayah kesatuan hukum adat. Pemekaran pemerintahan nagari pada prinsipnya hanya melakukan pembagian wilayah penyelenggaraan urusan pemerintahan guna mempersingkat rentang kendali pelayanan sehingga diharapkan mampu meningkatkan kualitas pelayanan publik dan mempercepat terwujudnya kesejahteraan masyarakat

Berdasarkan Peraturan daerah Kabupaten Pesisir Selatan Nomor 75 tahun 2011 tentang pembentukan pemerintahan nagari Pasar Lama Muara Air Haji di Kecamatan Linggo Sari Baganti yang telah disahkan pada tanggal 30 Juni 2011, maka Pemekaran Pemerintahan Nagari adalah tindakan memekarkan Pemerintahan Nagari dari 1 (satu) Pemerintahan Nagari awal menjadi 2(dua) atau lebih Pemerintahan Nagari baru, yang sebelumnya masuk dalam pemerintahan Nagari Air Haji.

\subsection{Keadaan Demografi}

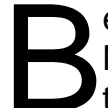
erdasarkan data kependudukan Nagari Pasar Lama Muara Air Haji tahun 2013, jumlah penduduk sebanyak 2.798 jiwa orang, dengan penduduk laki-laki berjumlah 1.349 jiwa dan penduduk perempuan 1.449 jiwa orang. Jumlah kepala keluarga (KK) adalah 735. Untuk lebih jelasnya mengenai komposisi penduduk Nagari Pasar Lama Muara Air Haji berdasarkan tingkat umur dapat dilihat dalam tabel dibawah ini. 
Tabel 2. Komposisi Penduduk dan Tingkat Umur di Nagari Pasar Lama Muara Air Haji Berdasarkan Jenis Kelamin

\begin{tabular}{|c|l|c|}
\hline No. & \multicolumn{1}{|c|}{ Uraian } & Jumlah \\
\hline 1 & Kependudukan & \\
\hline & A.Jumlah Penduduk (Jiwa) & 2.798 \\
\hline & B. Jumlah KK & 735 \\
\hline & C. Jumlah laki-laki & 1.349 \\
\hline & a. $0-15$ tahun & 275 \\
\hline & b. $16-59$ tahun & 839 \\
\hline & c. Diatas 60 tahun & 235 \\
\hline \hline & D. Jumlah perempuan & 1.449 \\
\hline & a. $0-15$ tahun & 280 \\
\hline & b. $16-59$ tahun & 954 \\
\hline & c. Diatas 60 tahun & 215 \\
\hline
\end{tabular}

Sumber: Profil Pasar Lama Muaro Air Haji, 2013

Berdasarkan hasil wawancara diperoleh bahwa jumlah penduduk terbanyak di Nagari Pasar Lama Muara Air Haji yang dikategorikan pada usia produktif berada pada tingkat umur antara 20 tahun hingga 50 tahun. Hal tersebut terkait erat dengan berbagai pekerjaan yang ditekuni oleh masyarakat di Nagari Pasar Lama Muara Air Haji.

\subsubsection{Mata Pencaharian}

$\mathrm{D}$ alam pemenuhan kebutuhan hidup masyarakat di Nagari Pasar Lama Muara Air Haji, baik kebutuhan dasar seperti kebutuhan sandang, pangan dan papan maupun kebutuhan sekunder seperti kebutuhan pendukung lainnya sangat diperlukan mata pencaharian untuk mencapai usaha tersebut. Dalam pemenuhan kebutuhan tersebut, di dalam masyarakat mempunyai mata pencaharian yang beragam/bervariasi. Demikian juga dengan masyarakat Nagari Pasar Lama Muara Air Haji yang memiliki beragam mata pencaharian. Berikut ini data mengenai persentase penduduk berdasarkan variasi mata pencaharian di Nagari Pasar Lama Muara Air Haji.

Tabel 3. Jumlah Penduduk Nagari Pasar Lama Muara Air Haji Menurut Mata Pencaharian

\begin{tabular}{|c|l|c|c|}
\hline No. & \multicolumn{1}{|c|}{ Jenis Mata Pencaharian } & Jumlah & $\%$ \\
\hline 1 & Petani & 44 & 5 \\
\hline 2 & Buruh & 245 & 29 \\
\hline 3 & Nelayan & 59 & 7 \\
\hline 4 & Pedagang & 40 & 5 \\
\hline 5 & Jasa & 15 & 2 \\
\hline 6 & PNS/ABRI & 20 & 2 \\
\hline 7 & Tidak Bekerja & 421 & 50 \\
\hline \multicolumn{2}{|c|}{ JUMLAH } & 844 & 100 \\
\hline
\end{tabular}

Sumber: Profil Pasar Lama Air Haji, 2013

Berdasarkan tabel diatas menunjukkan bahwa sebagian besar penduduk di Nagari Pasar Lama Muara Air Haji bermata pencaharian sebagai petani, buruh dan nelayan, terutama nelayan buruh sebanyak 59 (7\%). Di samping, persentase masyarakat yang tidak bekerja di nagari tersebut cukup tinggi (50\%). Hal ini menyebabkan wilayah ini rawan terhadap tindakan kriminal dan tingkat keamanan 
rendah. Kondisi ini juga diperkuat dengan wilayah yang merupakan lintas jalan yang menghubungkan antara propinsi Sumatera Barat dengan propinsi Bengkulu.

\subsubsection{Tingkat Pendidikan}

$\mathrm{P}$ endidikan merupakan kebutuhan utama masyarakat di Nagari Pasar Lama Muara Air Haji sebagai usaha untuk menambah ilmu pengetahuan mereka dan juga mengangkat pada derajat yang lebih tinggi. Kesadaran masyarakat di Nagari Pasar Lama Muara Air Haji terhadap pentingnya pendidikan cukup tinggi dimana sebagian besar masyarakatnya sudah mengenyam pendidikan padan tingkat SMP dan SMA. Meskipun demikian, sebagian masyarakatnya juga ada yang menamatkan pendidikan hanya pada tingkat SD. Hal tersebut dapat dilihat pada data tingkat pendidikan di Nagari Pasar Lama Muara Air Haji berikut ini:

\section{Tabel 4. Jumlah Penduduk Nagari Pasar Lama Muara Air Haji}

Menurut Tingkat Pendidikan

\begin{tabular}{|c|l|c|c|}
\hline No. & \multicolumn{1}{|c|}{ Tingkat Pendidikan } & Jumlah & $\%$ \\
\hline 1 & Tidak Tamat SD & 230 & 25 \\
\hline 2 & SD/Sederajat & 350 & 39 \\
\hline 3 & SMP/Sederajat & 166 & 18 \\
\hline 4 & SMA/Sederajat & 145 & 17 \\
\hline 5 & Akademi/Perguruan Tinggi & 12 & 1 \\
\hline JUMLAH & 903 & 100 \\
\hline
\end{tabular}

Sumber: Profil Pasar Lama Air Haji, 2013

Berdasarkan data tersebut diatas menunjukkan bahwa tingkat pendidikan di Nagari Pasar Lama Muara Air Haji terbilang masih rendah. Hal tersebut diperlihatkan melalui jumlah penduduk yang telah menamatkan pendidikan sebagian besar adalah tamat SD (39\%), diikuti SMP (18\%) dan SMA (17\%) dan perguruan tinggi sebanyak 12 (1\%). Meskipun demikian, diperoleh juga terdapat penduduk yang tidak menamatkan pendidikan SD (25\%). Pada umumnya, mereka yang tidak menamatkan pendidikan SD dikarenakan faktor ekonomi dan kesempatan.

Hasil pembangunan di bidang pendidikan di Nagari Pasar Lama Muara Air Haji masih belum mengembirakan. Akses masyarakat terhadap pendidikan masih belum mencapai target yang diinginkan. Pada 2007, akses pendidikan bagi anak usia sekolah dasar dan lanjutan pertama (umur 7-15 tahun) baru mencapai sekitar $50 \%$. Dengan demikian masih terdapat $13 \%$ anak usia sekolah lanjutan pertama di daerah ini yang belum mendapat pendidikan. Hal ini disebabkan antara lain karena sarana pendidikan relatif jauh dari kampung; beban ekonomis sekolah yang semakin berat; dan kondisi ekonomi keluarga

yang semakin susah. Tingkat kemampuan tulis baca masyarakat juga masih belum memuaskan. Pada 2013, angka melek huruf orang dewasa (umur 15 tahun ke atas) di Pesisir Selatan sekitar $91,2 \%$. Artinya, pada kalangan penduduk dewasa di nagari ini masih terdapat sebesar $8,8 \%$ yang belum bisa tulis baca huruf latin. Di samping itu, mutu pendidikan ternyata juga masih tertinggal dibandingkan daerah lain di Sumatera Barat. Hal ini disebabkan oleh, antara lain, rendahnya kompetensi guru, kurangnya fasilitas pembelajaran, dan rendahnya partisipasi orang tua terhadap pendidikan anak-anaknya.

Untuk menunjang aktivitas pendidikan masyarakat di Nagari Pasar Lama Muara Air Haji sangat dibutuhkan sarana dan prasarana agar tujuan pendidikan dapat tercapai. Adapun sarana pendidikan yang terdapat di Nagari Pasar Lama Muara Air Haji dapat dilihat pada tabel berikut ini: 
Tabel 5. Sarana Pendidikan di Nagari Pasar Lama Muara Air Haji

\begin{tabular}{|c|l|c|}
\hline No. & \multicolumn{1}{|c|}{ Sarana Pendidikan } & Jumlah \\
\hline 1 & Taman Kanak-Kanak (TK) & 2 \\
\hline 2 & Sekolah Dasar (SD) & - \\
\hline 3 & Sekolah Menengah Pertama (SMP) & 1 \\
\hline 4 & Sekolah Menengah Atas (SMA) & - \\
\hline 5 & Akademi/Perguruan Tinggi & 4 \\
\hline
\end{tabular}

Sumber: Profil Pasar Lama Air Haji, 2013

Berdasarkan tabel diatas menunjukkan bahwa jumlah sarana pendidikan di Nagari Pasar Lama Muara Air Haji kurang memadai dengan tersedianya sarana pendidikan SD dan SMA. Hal tersebut memperlihatkan tingkat pendidikan masyarakat belum merata dan terbilang masih rendah dikarenakan fasilitas pendidikan kurang memadai.

\subsection{Pola Pemukiman Nagari Pasar Lama Muara Air Haji}

Ola pemukiman adalah wujud dari bentuk pemukiman pada suatu daerah yang meliputi pola letak tempat tinggan dan bentuk rumah di pemukiman tersebut. Pola letak pemukiman di Nagari Pasar Lama Muara Air Haji tidak berbeda jauh dengan pola pemukiman wilayah pesisir di daerah lain, dimana rumah-rumah membentang sepanjang pantai di pesisir pantai Air Haji.

Pola pemukiman Nagari Pasar Lama Muara Air Haji yang mengikuti garis pantai dimulai dari Jorong Kampung Muara Air Haji, kemudian dilanjutkan menuju Jorong Kampung Pasar Lama. Untuk menuju Nagari tersebut, dapat ditempuh dengan kendaraan beroda dua dan empat dengan sarana jalan yang cukup baik sehingga dapat ditempuh selama 4 jam perjalanan dari ibu kota Sumatera Barat, yaitu kota Padang.

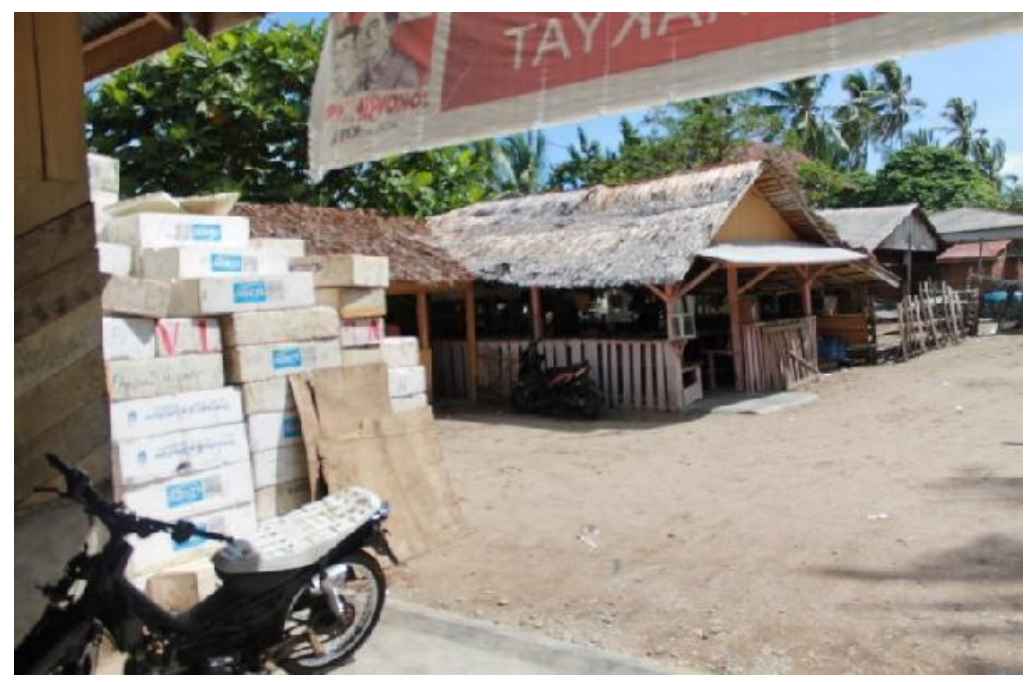

Gambar 2. Salah satu kondisi pemukiman penduduk di pantai Nagari Pasar Lama Muara Air Haji

Kepemilikan rumah yang berada di sekitar pantai adalah sebagian besar dimiliki oleh rumah tangga nelayan buruh dan juga pedagang ikan berskala kecil. Pada umumnya, bentuk rumah di Nagari Pasar Lama Muara Air Haji, terutama kampung- kampung di sekitar pantai terdiri dari rumah tidak permanen dan semi permanen dan hanya beberapa rumah saja yang permanen, yaitu sekitar 5-10 rumah. Untuk rumah-rumah yang berada di sekitar jalan utama yang menghubungkan antar jorong di 
Nagari Pasar Lama Muara Air Haji, keadaannya lebih baik dari rumah yang ada di dekat pantai. Biasanya rumah-rumah di wilayah ini dihuni oleh pedagang ikan dengan skala yang lebih besar dibandingkan dengan pedagang yang ada di pinggir pantai.

Berdasarkan observasi (melalui pengamatan), terdapat beberapa rumah di pemukiman sekitar wilayah pantai (5-10 rumah) yang dihuni oleh para nelayan yang tidak layak untuk menjadi tempat tinggal. Rumah mereka hanya beralaskan pasir pantai dan berdindingkan kayu dan juga atapnya terbuat dari seng yang sudah berkarat dan berlubang.

Di sekitar pemukiman nelayan, terdapat 2-4 warung makanan yang selalu dipenuhi oleh para nelayan buruh, terutama sekali ketika mereka sudah selesai melaksanakan aktivitas penangkapan ikan seperti memukat dan juga pada saat terjadinya badai (cuaca tidak baik). Aktivitas yang biasa mereka lakukan adalah berdiskusi tentang aktivitas penangkapan ikan, bermain domino/kartu dan hanya sekedar minum kopi.

\subsection{Aktivitas Sosial Budaya Masyarakat}

$\mathrm{M}$ asyarakat di Nagari Pasar Lama Muara Air Haji hampir seluruhnya beragama Islam, hanya $0,01 \%$ saja yang non-muslim. Dengan demikian, ketersediaan sarana dan prasarana ibadah, masjid dan mushalla, menjadi keharusan untuk kenyamanan mereka dalam menjalankan ibadah.

Sebagai orang Minangkabau yang menganut sistem matrilineal, Masyarakat di Nagari Pasar Lama Muara Air Haji pada umumnya berasal dari Kabupaten Solok dan Solok Selatan, seperti Muaralabuh, Muaropaneh, Koto Anau, Sungai Pagu, Alahan Panjang, Lubuk Sikarah, Lubuk Gadang dan sebagainya. Oleh karena itu, secara sosial budaya penduduk daerah ini masih mempunyai hubungan dengan beberapa nagari di Solok dan Solok Selatan.

Oleh karena itu, sistem pemilikan dan penguasaan tanah di daerah ini tunduk kepada Hukum Adat Minangkabau yang mengenal tanah pusako dan ulayat (nagari), dengan kepemimpinan adat tungku tigo sajarangan (ninik mamak, ulama dan cerdik pandai). Pada masa kolonial, daerah ini juga pernah didiami oleh etnis non-Minangkabau seperti Cina, Jawa, Bugis, Batak, Aceh dan Muko-muko. Pada umumnya mereka telah membaur dengan kehidupan sosial budaya orang Minangkabau. Namun, sekarang tidak lagi etnis Cina yang menjadi Masyarakat di Nagari Pasar Lama Muara Air Haji.

Partisipasi dalam pembangunan di daerah ini sangat tinggi. Hampir semua sarana dan prasarana publik dibangun di atas tanah adat yang diserahkan oleh masyarakat hukum adat baik tanah pusako maupun tanah ulayat nagari. Potensi ini bisa menjadi keunggulan bagi daerah ini dalam pengadaan tanah untuk pembangunan. Sebagaimana lazimnya orang Minang, masyarakat Pesisir Selatan juga terkenal dengan budaya lisan. Hal ini melahirkan jenis kesenian anak nagari yang populer di daerah ini yaitu kesenian lisan Rabab Pasisie yang menggunakan biola dan nyanyian vokal. Sementara itu, seni bela diri Pencak Silat juga berkembang baik di daerah ini.

\subsection{Aktivitas Penangkapan Ikan}

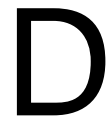
alam aktivitas penangkapan ikan yang dilakukan oleh nelayan pada umumnya dilakukan secara berkelompok tetapi ada juga yang melakukannya secara perorangan. Kegiatan tersebut sebagian besar dilakukan oleh pihak laki-laki yang berumur diatas 15 tahun. Pendapatan nelayan di Nagari Pasar Lama Muara Air Haji berkisar antara Rp.25.000,hingga Rp. 100.000,-. Pendapatan nelayan termasuk rendah dikarenakan sebagian besar nelayan di Nagari Pasar Lama Muara Air Haji tersebut adalah nelayan buruh (60\%).

Aktivitas penangkapan ikan pada masyarakat nelayan Nagari Pasar Lama Muara Air Haji, yaitu aktivitas membagan, memayang dan memukat. Teknologi pada penangkapan ikan menjaring menggunakan peralatan jaring (Wareng) dan perahu dengan menggunakan mesin tempel. Jaring yang selalu dipergunakan oleh masyarakat nelayan Nagari Pasar Lama Muara Air Haji adalah yang berukuran 100-200 m. Jaring ini ada yang jahitannya halus dan kasar. Jaring yang halus ukuran matanya memiliki panjang $25-20 \mathrm{~cm}$ dan lebarnya kira-kira 5 $\mathrm{cm}$, sedangkan jaring yang jahitannya kasar 
ukuran matanya memiliki panjang $50-60 \mathrm{~cm}$ dan lebar $10 \mathrm{~cm}$.

Untuk jahitan yang kasar adalah untuk menangkap ikan yang besar-besar seperti ikan gembolo, ikan gurigak, belatuk dan soaso, sedangkan jahitan yang halus atau rapat adalah untuk menangkap ikan yang kecil-kecil seperti ikan campu, pinangpinang, maco dan tete. Untuk menangkap ikan dengan menjaring mempergunakan sebuah perahu yang panjangnya lebih kurang $4 \mathrm{~m}$ dan lebarnya $1 \mathrm{~m}$. Perahu yang banyak digunakan oleh masyarakat nelayan Nagari Pasar Lama Muara Air Haji saat ini sudah banyak memakai mesin perahu/mesin tempel.

Hasil tangkapan ikan yang diperoleh langsung di bawa ke tempat pelelangan ikan yang berada di Jorong Kampung Muara Air Haji dan disana sudah ada agen atau pembeli yang menanti. Biasanya agen-agen tersebut telah ditentukan oleh induk semang. Alasan lain nelayan menjual ikan di tempat tersebut karena semua jenis ikan dapat diterima baik besar maupun kecil, begitu juga dengan jenis-jenisnya.

Nagari Pasar Lama Muara Air Haji merupakan Nagari yang memiliki potensi sumber daya alam laut yang dengan garis pantai sepanjang $\pm 6 \mathrm{~km}$ dan disertai dengan Tempat Pendaratan Ikan (TPI) beserta fasilitas penunjang lainnya. Potensi hasil laut nagari Nagari Pasar Lama Muara Air Haji telah menjadi salah satu andalan ekonomi yang utama dari Nagari Pasar Lama Muara Air Haji. Dari segi infrastruktur dan perhubungan Nagari Pasar Lama Muara Air Haji dilalui oleh jalan negara yang menghubungkan lbukota Propinsi dan Ibukota Kabupaten.

Berdasarkan klasifikasi Masyuri dalam Lucky Zamzami (2009:39) bahwa ciriciri nelayan buruh atau dikatakan nelayan tradisional ditandai dengan (a) kegiatan mereka yang lebih banyak menggunakan padat, kalaupun menggunakan mesin, ukuran atau tenaga mesin relatif kecil atau motor tempel dengan menggunakan alat tangkap yang sederhana; (b) teknologi yang dipakai untuk penangkapan atau pengolahan ikan yang masih sederhana dan (c) tingkat pendidikan dan keterampilan yang rendah. Ciri-ciri tersebut diatas dibuktikan dengan peralatan penangkapan ikan yang sederhana seperti perahu (biduak) yang memakai mesin tempel, alat pancing/jala sehingga hasilnya sangat berbeda jauh dengan peralatan nelayan modern.

Keterbatasan potensi serta modal usaha nelayan di Nagari Pasar Lama Muara Air Haji yang memiliki pengertian nelayan yang bekerja dengan alat tangkap milik orang lain. Mereka harus membagi hasil tangkapannya dengan nelayan juragan (yang memiliki peralatan) sampai $65 \%$ dengan pembagian $50 \%$ untuk nelayan juragan dan $15 \%$ untuk mengatasi kerusakan.

Aktivitas penangkapan ikan yang dilakukan oleh nelayan Nagari Pasar Lama Muara Air Haji hampir sama dengan aktivitas penangkapan ikan lainnya di berbagai daerah di wilayah pantai Barat Sumatera. Aktivitas penangkapan ikan yang dilakukan oleh nelayan buruh di wilayah pesisir pantai Selatan Sumatera Barat adalah membagan, memayang, memukat, menjaring dan memancing (Zamzami, 2008,2009).

Salah satu faktor penting dalam aktivitas nelayan Nagari Pasar Lama Muara Air Haji adalah menjual hasil penangkapan ikan. Hasil produksi berupa ikan yang telah ditangkap di laut oleh nelayan buruh merupakan produksi ikan yang cepat rusak sehingga harus segera dipasarkan. Kondisi ini menyebabkan para nelayan buruh menjual hasil tangkapannya secepatnya setelah berlabuh di tepi pantai. Biasanya hasil tangkapan para nelayan buruh akan langsung dijual di pinggir pantai, dimana di tempat tersebut telah menunggu para pedagang (toke') dan juga pengolah ikan untuk membeli hasil tangkapan mereka. Dalam proses penjualan ikan tersebut, nelayan buruh langsung berhubungan dengan para pedagang atau pengolah ikan tanpa ada perantara.

Harga ikan yang dijual oleh nelayan di Nagari Tiku Selatan bervariasi sesuai dengan jenis ikan yang ditangkap, yaitu:

a. Ikan Bulato (ikan Kembung) $1 \mathrm{~kg}$ seharga Rp. 13.000,-

b. Ikan Gabua $1 \mathrm{~kg}$ seharga Rp. 15.000

c. Ikan Kaliang-kaliang $1 \mathrm{~kg}$ seharga Rp. 7.000,-

d. Ikan Tongkol $1 \mathrm{~kg}$ seharga Rp. 10.000

e. Ikan Tambolo $1 \mathrm{~kg}$ seharga $\mathrm{Rp}$. 14.000,- 
f. Ikan Bowl putih $1 \mathrm{~kg}$ seharga Rp.40.000,-

g. Ikan Bowl hitam $1 \mathrm{~kg}$ seharga Rp.20.000,-

h. Ikan Tenggiri Aceh $1 \mathrm{~kg}$ seharga Rp. 20.000,-

i. Ada juga terdapat pengolahan bada teri (ikan teri), namun jarang karena ikan teri lumayan sulit di dapat.

\subsection{Teknologi Penangkapan Ikan}

U ntuk aktivitas penangkapan ikan yang dilakukan oleh nelayan di Nagari Pasar Lama Muara Air Haji terdapat teknologi penangkapan yang digunakan dalam mencari ikan, yaitu:

a. Kapal Bagan, kapal yang cukup besar menggunakan mesin sebagai penggerak kapal, dan memiliki lampu sebagai penarik ikan. Biasanya kapal bagan dapat ditemukan di daerah Suranti.

b. Kapal Tondo atau kapal boat, yaitu kapal dengan mesin disel seperti boat.

c. Pompong, kapal yang menggunakan tenda

d. Payang, yaitu biduak atau perahu bercadik.

e. Robin, yaitu perahu dengan menggunakan mesin robin atau mesin tempel seperti speedboat. Biasanya hanya untuk 2 orang.

f. Sampan Boling yaitu sampan biasa dengan menggunakan dayung saja. Untuk aktivitas penangkapan ikan di Nagari Pasar Lama Muara Air Haji, terdapat hari di mana para nelayan buruh tidak diperbolehkan melaut, yaitu pada hari jum'at. Pada hari Jum'at tersebut para buruh nelayan hanya fokus beribadah (shalat Jum'at) terutama bagi yang laki-laki dimana kalau ada yang melanggar maka nelayan buruh yang melakukan akan mendapatkan sanksi sosial seperti cemoohan dari masyarakat. Kemudian saat ada kematian, buruh nelayan harus melayat ke rumah jenazah dan mengikuti prosesproses upacara kematian sebagai penghormatan kepada orang yang sudah meninggal.

Biasanya para nelayan Nagari Pasar Lama Muara Air Haji ketika ke laut dilakukan pada pagi hari sekitar pukul 06.30 Wib, kemudian kembali pada pukul 16.00
Wib. Kegiatan tersebut dikatakan tidak menentu dimana tergantung kepada hasil tangkapan ikan. Untuk melakukan penangkapan ikan pada malam hari, tidak banyak dilakukan oleh para nelayan buruh dikarenakan kondisi fisik nelayan buruh dan penggunaan perahu sebatas payang dan perahu tanpa mesin.

Cara penangkapan ikan di Nagari Pasar Lama Muara Air Haji terbagi ke dalam 2 bagian, yaitu membagan dan memukat. Cara memukat sekarang tidak lagi ditarik dengan menggunakan tenaga manusia tetapi sudah ditarik menggunakan perahu speedboat, dengan nama lokalnya yaitu "pukat hamparan dasar". Di Nagari Pasar Lama Muara Air Haji, masyarakat nelayan lebih banyak menggunakan pukat daripada bagan, karena menurut mereka pukat jauh lebih besar kadang-kadang dari segi hasil berbanding terbalik dengan bagan. Bagan biasa membawa 15 orang, 1 orang Tungganai (tukang kemudi) atau Tekong (istilah orang Sibolga), anak buah kapal ditambah dengan anak pancing (= anaka kaie-----nelayan buruh). Bagan menggunakan alat Wareng. Wareng biasanya dibingkai, diturunkan ke laut dengan ukuran 25 kali 25 meter dan biasanya diturunkan jam 9 malam memakai lampu petromaks. Alat Wareng ini bisa diturunkan sampai 3 kali.

Ikan yang didapat oleh nelayan buruh biasanya mereka jual tanpa harus menyetor uang kepada pemilik bagan. Pembagian hasil ikan yang diperoleh oleh nelayan biasa dibagi $2 / 3$ untuk induk semang, 1/3 inilah yang dibagi untuk $A B K$. Tungganai mendapat agak banyak dari $A B K$ dan anak pancing.

Untuk metode penangkapan ikan ada disebut dengan istilah "mondok", dimana nelayan yang akan melaut biasanya memakan sampai 4 hari dan mereka harus menyiapkan bekal yang mau dimakan di tengah laut. Untuk hal semacam ini, anak pancing juga ikut makan dengan bekal tersebut. Hal tersebut sudah menjadi sebuah tradisi di kalangan mereka. Selain melaut selama beberapa hari, ada juga nelayan yang hanya pulang pergi dalam sehari.

Dalam 1 bulan, efisien nelayan bisa melaut selama 15 hari. Untuk 15 hari ke depan maka mereka biasanya makan diwarung dengan cara mengutang dan 
dibayar duluan oleh induk semang. Hal ini sebetulnya sama dengan hutang yang nantinya harus dibayar dengan memotong pemasukan dari nelayan tersebut.

Jenis hasil tangkapan ikan di laut sangat terpengaruh oleh faktor cuaca. Ada 2 istilah, yaitu 1 kalam sanjo bulan 18/25 bulan muncul, mulai jam 8-9 malam. Artinya jaring Wereng harus diturunkan senja sebelum bulan muncul. Kalam panjang bulan 27/28 sampai hari ke 5 muncul kecil, tergantung situasi apakah ikan akan datang atau tidak.

Ikan/lauak diistilahkan dengan lauk biaso dan lauk jalang. Penamaan ikan jalang dikarenakan ikan cepat naik keatas, yang masuk kelompok ikan jalang seperti ikan sisiak, ambu-ambu, balang/tongkol. Ini biasanya dengan jaring wereng akan jarang diperoleh. Sedangkan untuk bada/ikan kecil tidak bisa karena disini hasilnya harus diderek pelan-pelan.

\section{KESIMPULAN DAN SARAN \\ 1. Kesimpulan}

$\mathrm{H}$ asil studi menunjukkan bahwa dalam aktivitas penangkapan ikan yang dilakukan oleh nelayan pada umumnya dilakukan secara berkelompok dan perorangan, sebagian besar dilakukan oleh pihak laki-laki yang berumur diatas 15 tahun. Pendapatan nelayan di Nagari Pasar Lama Muara Air Haji berkisar antara Rp.25.000,- hingga Rp. 100.000,-. Pendapatan nelayan termasuk rendah dikarenakan sebagian besar nelayan di Nagari Pasar Lama Muara Air Haji tersebut adalah nelayan buruh (60\%).

Aktivitas penangkapan ikan pada masyarakat nelayan Nagari Pasar Lama Muara Air Haji, yaitu aktivitas membagan, memayang dan memukat. Teknologi pada penangkapan ikan menjaring menggunakan peralatan jaring (Wareng) dan perahu dengan menggunakan mesin tempel. Hasil tangkapan ikan yang diperoleh langsung di bawa ke tempat pelelangan ikan yang berada di Jorong Kampung Muara Air Haji dan disana sudah ada agen atau pembeli yang menanti. Biasanya agen-agen tersebut telah ditentukan oleh induk semang. Alasan lain nelayan menjual ikan di tempat tersebut karena semua jenis ikan dapat diterima baik besar maupun kecil, begitu juga dengan jenis-jenisnya.

Nagari Pasar Lama Muara Air Haji merupakan Nagari yang memiliki potensi sumber daya alam laut yang dengan garis pantai sepanjang $\pm 6 \mathrm{~km}$ dan disertai dengan Tempat Pendaratan Ikan (TPI) beserta fasilitas penunjang lainnya. Potensi hasil laut nagari Nagari Pasar Lama Muara Air Haji telah menjadi salah satu andalan ekonomi yang utama dari Nagari Pasar Lama Muara Air Haji. Dari segi infrastruktur dan perhubungan Nagari Pasar Lama Muara Air Haji dilalui oleh jalan negara yang menghubungkan lbukota Propinsi dan lbukota Kabupaten.

\section{Saran}

a. Pemerintah lebih memperhatikan nelayan-nelayan buruh dalam hal membuka akses kepada mereka akan teknologi alat tangkap ikan, sehingga kesejahteraan rumah tangga nelayan buruh semakin meningkat.

b. Pemerintah membentuk koperasi yang profesional untuk membantu nelayan-nelayan buruh mendapatkan akses teknologi alat tangkap ikan.

\section{Daftar Pustaka}

Alimuddin, M. Ridwan, 2005, Orang Mandar Orang Laut: Kebudayaan bahari Mandar Mengaruni Gelombang Perubahan zaman, Jakarta: KPG bekerjasama dengan yayasan Adikarya IKAPI

Altman, Irwin, et.all, (ed), 1980, Human Behavior and Environment Advances in Theory and Research, New York an London: Plenum Press.

Budi, S. 2008. Kemiskinan dan Perlawanan Kaum Nelayan. Malang: Laskbang Mediatama.

Charles, T.A. 2001. Sustainable Fishery System. London: Blackwell Science.

Dahuri, Rokhmin, dkk, 2004, Budaya Bahari: Sebuah Apresiasi di Cirebon, Jakarta: Perum Percetakan Negara RI. 
Dirjen Kebudayaan Depdikbud, 1997, Budaya Kerja Nelayan Indonesia di Jawa Timur, Jakarta: CV Bupara Nugraha

Harian Haluan Padang Sumatera Barat, 4 April 2001, Artikel Potensi Kelautan Indonesia

Iskandar, Meiwita B. dan Siti Rochmawati Darwisyah, 1999, Dampak Krisis Ekonomi Terhadap Kesehatan Masyarakat Rentan, Jakarta: Pusat Komunikasi Berspektif Jender.

Jurnal Antropologi, 2005, "Pemberdayaan Masyarakat Nelayan", dalam Tulisan Damsar dan Nia Elfina, Padang: Laboratorium Antropologi Edisi 9 Thn VI/2005

Kusnadi, 2002, Konflik Sosial Nelayan: Kemiskinan dan Perebutan Sumber Daya Perikanan, Yogyakarta: LkiS

2005, Akar Kemiskinan Nelayan, Yogyakarta: LkiS

2008. Nelayan: Strategi Adaptasi dan Jaringan Sosial. Bandung: Humaniora Utama Press

Luky, A. Hartato. 2009. Peningkatan Kapasitas untuk Pengarus-Utamaan Ko-Manajemen Perikanan di Indonesia. Jakarta: FOA dan DKP

Mubyarto, Dkk, Nelayan dan Kemiskinan, Yayasan Agri Ekonomika

Muflikhati, I. 2010. Kondisi Sosial Ekonomi dan Tingkat Kesejahteraan Keluarga: Kasus di Wilayah Pesisir Jawa Barat. Jurnal Ilmu Keluarga, 2-10.

Prihandoko, 2011. "Faktor-Faktor yang Mempengaruhi Perilaku Nelayan Artisanal dalam Pemanfaatan Sumber Daya Perikanan di Pantai Utara Propinsi Sumatera Barat" dalam Jurnal MAKARA: Sosial Humaniora, Vol. 15 No. 2 Desember 2011, 117-126. Jakarta: Universitas Indonesia.

Pramono, Djoko, 2005, Budaya Bahari, Jakarta: PT. Gramedia Pustaka Utama.

Satria, A. 2002. Pengantar Sosiologi Masyarakat Pesisir. Jakarta: PT. Pustaka Cidesindo.

Semedi, P. 2002. Close to the Stone, Far for The Throne, The Story of a Javanese Community 1980-1990. Yogyakarta: Benang Merah.

Solfema, 2002, Makalah "Wanita Dalam Masyarakat Nelayan : Latar Kehiudpan dan Potensi Pengembangannya", Disajikan dalam Seminar Budaya Pesisir dan Kondisi Potensi Kelautan Sumatera Barat, Museum Adityawarman Padang.

Marahudin Firial, 2002, "Kebijaksanaan Pembangunan Kelautan dan Perikanan, Sumatera Barat", Seminar di museum Adityawarman.

Sugiharto, Eko, dkk, 2013. "Studi Tingkat Kesejahteraan Masyarakat Nelatan di Kampung Gurimbang Kecamatan Sambaliung Kabupaten Berau" dalam Jurnal IImu Perikanan Tropis Vo. 18 No. 2 April 2013.

Zamzami, Lucky. 2007. "Pemanfaaatan Budaya Lokal Terhadap Teknologi Penangkapan Ikan pada Masyarakat Nelayan di Kelurahan Pasar Laban, Kecamatan Bungus Teluk Kabung, Kota Padang". Padang: Laporan Penelitian LP Unand. 